\title{
Knowledge Sharing in Organizational-Educational Context Case Study in Chamber of Deputies of Brazil
}

\author{
Roberto Campos da Rocha Miranda ${ }^{1}$, Cristina Jacobson Jácomo Cinnanti ${ }^{2}$ \& Maria Alice Gomes de Oliveira ${ }^{3}$ \\ ${ }^{1} \mathrm{PhD}$ in Information Science. MA in Legislative Affairs, Cefor. Chamber of Deputies of Brazil, Brazil \\ ${ }^{2}$ MSc in Psychology, House of Representatives of the Federal District, Brazil. \\ ${ }^{3}$ BSc in Psychology, Cefor. Chamber of Deputies of Brazil, Brazil \\ Correspondence: Roberto Campos da Rocha Miranda. Mestrado Profissional em Poder Legislativo. Programa de \\ Pós-Graduação. Centro de Formação, Treinamento e Aperfeiçoamento - CEFOR. Câmara dos Deputados, \\ 70160-900. Brasília, Brazil. E-mail: roberto.rocha@camara.leg.br
}

Received: July 20, 2015 Accepted: July 31, 2015 Online Published: October 29, 2015

doi:10.5539/par.v4n2p11 URL: http://dx.doi.org/10.5539/par.v4n2p11

\begin{abstract}
This paper aims to discuss which factors motivates MBA students to share knowledge and why they do that in spontaneous way, leading the group to create an effective "business" social networking in a public organization. The specific objectives of the chapter involve three points: (i) to identify differences and similarities on the process of sharing knowledge among students in two different classes of courses of the MBA Program at Chamber of Deputies; (ii) to apply theories of motivation on sharing knowledge in this particularly case; and (iii) to identify the effectiveness factors that motivates sharing knowledge in a "business social networking of scholar fellows". Methodology applied to this study involves a survey with 81 students, in three classes of the MBA courses: (i) Legislative and Public Policies (30 students), (ii) Legislative Process (30 students) and (iii) Legislative Public Management (21 students). Each class has particularities in its configuration that can influence the sharing knowledge process. Main results show that relationship and sense of self-worth are the most important motivation to promote the knowledge sharing and that Psychology theories contribute to understand this kind of phenomenon in an institutional-educational environment.
\end{abstract}

Keywords: knowledge management, business, social network, Chamber of Deputies, training, MBA

\section{Introduction}

Since 2005, the Chamber of Deputies in Brazil keeps a MBA program in fields related to Parliament, as Legislative Process, Political Institutions and Public Policies, Political Legislative Policies and others. There is a new course each summer and winter and each one of them lasts around 20 months.

A new group of students, around 30 by course, is composed by people from the Chamber of Deputies, Chamber of Deputies of the Federal District, Federal Senate and other Governmental Institutions related to the Parliament and it creates a natural business social networking. We define this special kind of social networking as a group of professionals enrolled on the same focus on continuous learning and growing, and that creates a connection by exchanging believes insights and mostly experiences about their life job. These are the fundamentals of socializing knowledge defined by Nonaka and Takeuchi (1995) as the conversion of tacit knowledge in tacit knowledge.

Thus, in this paper, three fundamental theories are put together to create a framework to discuss the main aspects that support the sharing of knowledge in an organizational-educational context. We can describe the interaction of those aspects on Figure 1. 


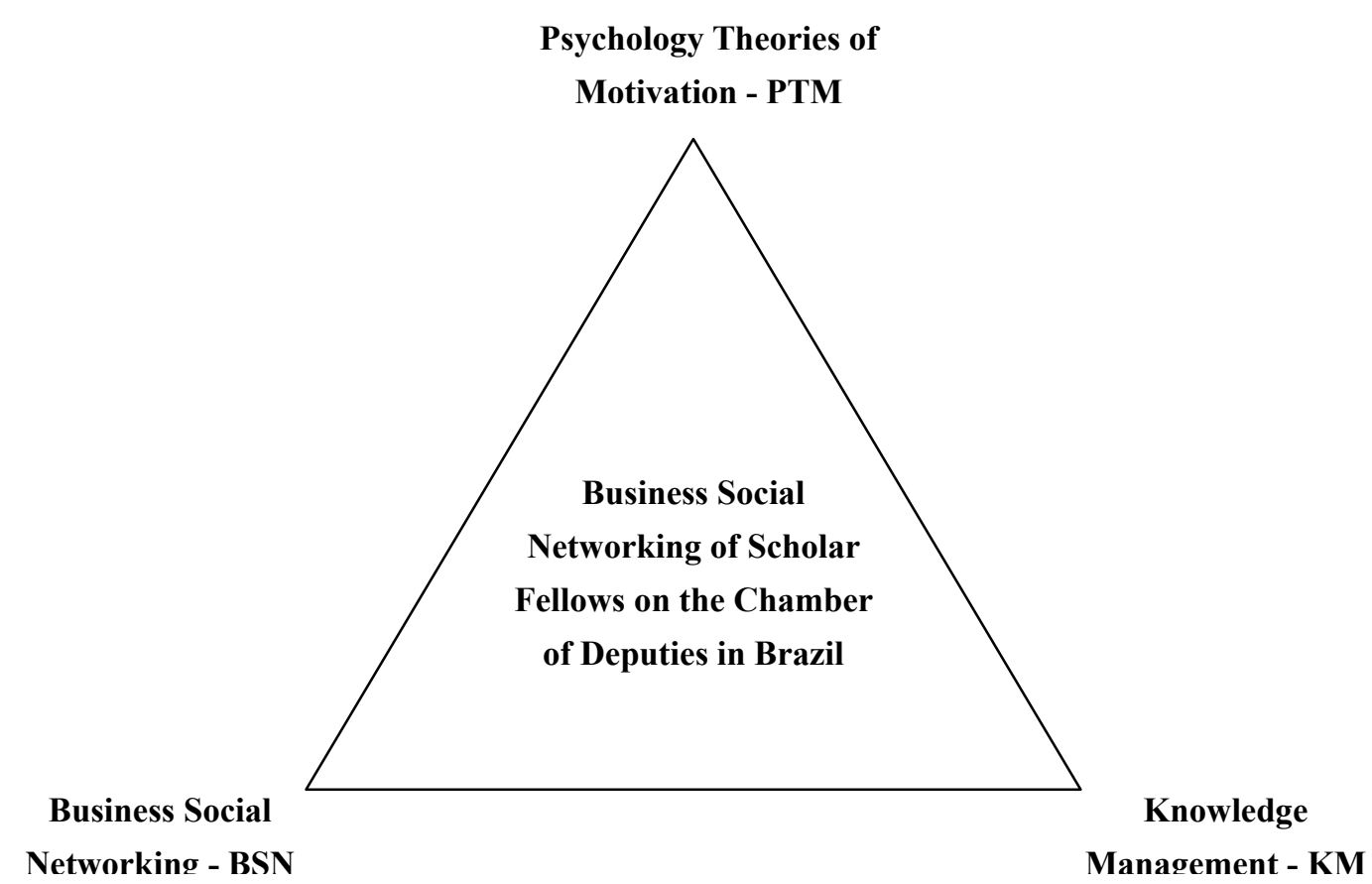

Figure 1. Aspects of Sharing Knowledge in an organizational-educational context

The conceptual framework allied with a survey with students of three courses of the MBA Program at Chamber of Deputies lead us to reach the follow objectives:

(i) Identify differences and similarities on the process of sharing knowledge, creating the possibility to establish some pattern that can be used in whole organization.

(ii) Evaluate the theories of motivation applied on sharing knowledge in this particularly case, leading to better understand conditions, circumstances and context that involve knowledge socialization among MBA students of the Chamber of Deputies.

(iii) Identify the effectiveness factors that motivate sharing knowledge in a "business social networking of scholar fellows", considering the possibility to use these factors to amplify the business social networks among students of other course level on the Formation, Training and Improving Center Cefor of the Chamber of Deputies.

\section{Theoretical Framework}

As we said before, there are three aspects of sharing knowledge that support this study and it is important to express the fundamental concepts to build a theory. In this topic, each main theme will be described, as well as the features that impact the construction of a business social network.

But, firstly, we show our comprehension of each concept as follows:

- Knowledge Management can be considered a framework to create conditions in an organizational context to capture, organize, classify, share and use organizational knowledge that adds value to a process, a service, a product or a system (Nonaka \& Takeuchi, 1995).

- Social network is an informal relation structure where people share own information about friendship, kinship, common interest, work, financial exchange, relationships, beliefs, knowledge, prestige and others. This kind of network may be supported by ICT.

- Motivation is "a goal-directed action, self-regulated in a biological or cognitive way, persistent in time and activated by a set of needs, emotions, values, goals and expectations" (Gondim \& Silva, 2004).

\subsection{Knowledge Management}

According to Snowden (2006), the Knowledge Management Theory is increasing its features by "generations". The first generation is related to decision support systems and process massive information, in an approach similar to the Information Management. The second generation is based on the creation of knowledge in 
companies according to Nonaka and Takeuchi's theory, understanding the dichotomy - tacit and explicit knowledge - as well as using technology to support the sharing knowledge. The generation 3.0 returns to decision support, but in a new focus: sense-making, narrative and social networks as the key to an effective knowledge management.

Theoretical foundations of Knowledge Management (Baskerville \& Dulipovici, 2006) considers that knowledge process definition involves the organizational behavior that comprises organizational creativity, innovation, organizational learning and organizational memory, all topics related to the use of business social networking as a support to knowledge management.

This way to (re)think knowledge management improves the old one, in order to insert an applied vision of the process to transform tacit into explicit knowledge - renamed Articulated knowledge - (and all others combinations between them) in usable knowledge in organizations. Figure 2 shows this change.

\begin{tabular}{|c|c|c|c|c|c|c|}
\hline $\begin{array}{ll} & \text { From } \\
\text { To } & \end{array}$ & $\begin{array}{c}\text { Explicit } \\
\text { Knowledge }\end{array}$ & $\begin{array}{c}\text { Tacit } \\
\text { Knowledge }\end{array}$ & \multirow{3}{*}{$\begin{array}{c}\text { Applied } \\
\text { Vision }\end{array}$} & From & $\begin{array}{c}\text { Explicit } \\
\text { Knowledge }\end{array}$ & $\begin{array}{c}\text { Tacit } \\
\text { Knowledge }\end{array}$ \\
\hline $\begin{array}{c}\text { Explicit } \\
\text { Knowledge }\end{array}$ & Combination & Externalization & & $\begin{array}{c}\text { Explicit } \\
\text { Knowledge }\end{array}$ & (re)signification & Narratives \\
\hline $\begin{array}{c}\text { Tacit } \\
\text { Knowledge }\end{array}$ & Internalization & Socialization & & $\begin{array}{c}\text { Tacit } \\
\text { Knowledge }\end{array}$ & $\begin{array}{c}\text { Multi-sensory } \\
\text { resources }\end{array}$ & $\begin{array}{c}\text { Social } \\
\text { Networking }\end{array}$ \\
\hline
\end{tabular}

Figure 2. Applied vision of tacit and explicit knowledge transformation

(Adapted from Nonaka \& Takeuchi, 1995)

The first way to create knowledge is related to turn the information registered in a new significance, bringing together points that show a new way of treating a theme, creating (re)new signification to information already expressed.

In a second view, organizational context is facing new challenges in terms of human resources. The advance of technology and the possibility to access information from different sources and in a variety of formats turns employees into "antennas" that capture everything all around.

The third point is related to narratives. Also known as storytelling, this practice of knowledge management improves the organizational memory by creating conditions to capture tacit knowledge from experts.

At last, Social Network, in the context of Knowledge Management, can be seen as a locus where people can freely exchange ideas, expertise, feelings, values and all kind of personal features that characterizes the tacit knowledge. Processes of interaction between social network members stimulate the creativity and learning, depending on ties among these members (Argote \& Miron-Spektor, 2010). This configures a really knowledge transfer.

This kind of network in business context can assume two different configurations:

- Formal, when it is established by the organization structure and can be seen as teams, work groups etc.

- Informal, when it is developed by the employees by familiarity, empathy, proximity or mutual interest like in communities of practice (Wenger, 1999).

In this case, Knowledge Management is creating conditions that support the existence of networks that share knowledge, which can be useful to any kind of organizational decisions. When decisions are made on the top of the organization, a network of information and knowledge is accessed, formally and informally. It also happens when operational decisions are made, in a narrow.

This leads us to the factors that can improve or inhibit knowledge transfer and share, as shown on Table 1: 
Table 1. How factor affect knowledge management (Based on Stollenwerk, 2001)

\begin{tabular}{|c|c|c|}
\hline $\begin{array}{l}\text { Factor that affects } \\
\text { KM }\end{array}$ & In a good way & In a bad way \\
\hline Leadership & $\begin{array}{l}\text { Good leaders support the KM } \\
\text { process and stimulate knowledge } \\
\text { sharing }\end{array}$ & $\begin{array}{l}\text { Autocratic leaders can improve a low } \\
\text { level of creativity and innovation } \\
\text { among employees }\end{array}$ \\
\hline $\begin{array}{l}\text { Organizational } \\
\text { Culture }\end{array}$ & $\begin{array}{l}\text { Culture that emphasize confidence } \\
\text { and cooperation among employees }\end{array}$ & $\begin{array}{l}\text { If competition is the law, employees } \\
\text { are not encouraged to share } \\
\text { information or knowledge }\end{array}$ \\
\hline $\begin{array}{l}\text { Measure } \\
\text { evaluation }\end{array}$ & $\begin{array}{l}\text { The existence of indicators to } \\
\text { evaluate employee's behavior } \\
\text { factors can improve job activities by } \\
\text { giving feedback, recognition and } \\
\text { bonus to accomplished tasks }\end{array}$ & $\begin{array}{l}\text { Where everybody wins the same } \\
\text { recognition by different performance, } \\
\text { there is no motivation to achieve better } \\
\text { results on work }\end{array}$ \\
\hline Technology & $\begin{array}{l}\text { It is vital to use ICT in order to } \\
\text { share knowledge in large or small } \\
\text { scale, accessed everywhere, anytime } \\
\text { and in any format }\end{array}$ & $\begin{array}{l}\text { ICT cannot enslave employees and do } \\
\text { not represent all itself. It must be used } \\
\text { as support, not as the main aspect in } \\
\text { KM }\end{array}$ \\
\hline
\end{tabular}

At this point, it is important to establish differences among three kinds of people grouping on organizational context, in order to better understand the objectives of sharing knowledge in each case, as represented on Table 2:

Table 2. Differences among three kinds of people grouping on organizational context

\begin{tabular}{|c|c|c|c|}
\hline & Community of Practice & Social Network & Business Social Network \\
\hline Source & lated Learning & Social Anthropology & Social Science \\
\hline Goal & $\begin{array}{l}\text { Aggregate of people who } \\
\text { join because of } \\
\text { some specific topic of } \\
\text { study, a "passion" or a } \\
\text { problem }\end{array}$ & $\begin{array}{l}\text { Personal communities } \\
\text { that aims to organizing } \\
\text { schemes that help them } \\
\text { to solve their daily } \\
\text { problems }\end{array}$ & $\begin{array}{l}\text { Group of professionals organized to } \\
\text { expand relations and contacts within } \\
\text { and outside the organization, } \\
\text { facilitating and streamlining the work } \\
\text { routines and assisting in the } \\
\text { promotion of career }\end{array}$ \\
\hline Formality & Less formal & Less formal & More formal \\
\hline Participation & $\begin{array}{l}\text { Nuclear group, full } \\
\text { membership, peripheral } \\
\text { participation, and } \\
\text { transactional participation } \\
\text { and passive access }\end{array}$ & $\begin{array}{l}\text { It depends on the } \\
\text { network density }\end{array}$ & Active and intense \\
\hline $\begin{array}{l}\text { Motivation to } \\
\text { share }\end{array}$ & Find solutions & $\begin{array}{l}\text { Recognition and social } \\
\text { acceptance }\end{array}$ & Professional development \\
\hline Authors (ex.) & $\begin{array}{ll}\text { Eckert } & (2000), \text { Wenger } \\
(1999) & \end{array}$ & Milroy \& Gordon, 2003 & Gloor et alli, 2008 \\
\hline
\end{tabular}

\subsection{Business Social Networking}

Networks are defined, in a generic way, as wire interlacing forming a kind of tissue. In science dominion, this figure is used to study networks in their various representations and meanings. Humanities, Social, Exact and Biological Sciences, besides other investigation fields, think over networks as a study object, each one of them by their own perspectives. Even each investigation field focus on networks by its own way, trying to relate it to 
other relevant topics in its study area, the graphic picture of wires that intersect, forming knots and edges, is common to all fields dedicated to understanding the networks and their main aspects, like morphology, function, purpose, and, mainly, their power.

Our concern, at this moment, focuses on social networks - a topic pertinent to several areas like Psychology, Sociology, Knowledge and Information Management - and in particular, on business social networks.

Human beings cluster by interests, needs or affinities, forming social networks. Moreover, the relationships people develop over life determine the networks they belong. These networks tend to change over time, according to new bonds formed and broke (Tomaél, Alcará and Di Chiara, 2005).

Cavalcante (2009) sought to establish the epistemological foundations of what he calls Network's Science. He conceptualizes social network as "a form of representation of emotional or professional human beings relationships, among themselves, or between interest groups. Therefore, a social network comprises one or more finite sets of actors (and events) and all relationships defined among them" (Cavalcante, 2009, p. 43).

According to Cavalcante (2009), networks have universal properties that are applied to all of them, as well as contextual properties, which, though dependent on the characteristics of each one, can be found in most known networks, as shown on Table 3.

Table 3. Universal and contextual networks properties

\begin{tabular}{|c|c|}
\hline Universal properties & Contextual properties \\
\hline $\begin{array}{l}\text { - Structure: refers to network's topology, which } \\
\text { results from its knots connections. } \\
\text { - Autonomy: networks are composed by } \\
\text { autonomous elements connected. Their }\end{array}$ & $\begin{array}{l}\text { Emergency: this property relates to the emergence } \\
\text { or modification of properties in a network, } \\
\text { considering that local changes can reverberate and } \\
\text { promote changes in network properties as a whole. }\end{array}$ \\
\hline
\end{tabular}
performance will arise from the set of all the individual behaviors. Networks are not leaded by a central coordination.

- Dynamism: networks are dynamics, change and evolve over time.

- Evolution bottom-up: networks configuration is modified from changes in punctual interactions. Small local changes (new interactions or interactions disrupted) are reflected in global changes.

- Topology: networks topology depends on the quantity and quality of links established. Each link can be represented by the connection between two network elements. This bond can be strong or weak, and its intensity will influence network's topology.

- Potency: a knot's power depends on the amount of bonds that form it, on their position in the network and on its relevance.

- Navigation: refers to how to go through the paths on a network.

- Stability: this property appears when changes in network are not significant.

- Transitivity or clustering: clusters are formed in social networks, opposing to the random model of networks.

- Small-world effect: it assumes that an individual may be linked to any other, wherever located, by a short chain of social relations.

- Resilience: relates to network's ability to maintain itself, even with the exclusion of some of the bonds that comprise it.

- Structure of community: that property is commonly perceived in social networks. Some knots have high density in their connections, forming groups, and links between groups have lower density.

- Mixing patterns: some knots, by default, bind themselves to similar ones, while others knots bind systematically to knots with different properties than them. The analysis of a network connection patterns between knots provide much information about it.

- Distribution's degree by power's law model: there are nodes with few links or edges, and nodes with many of them, side by side in the same network.

- Grounds (patterns): respects to interconnection patterns in complex networks.

Source: Cavalcante (2009, p. 110-116). 
Tichy, Tuschman and Fombrum (1979, apud Lopes and Baldi, 2009), highlight three properties of networks as the most important: the transactional content, ie what is exchanged by the social actors; the nature of links, which refers to the quality and strength of any relationship established; and the structural characteristics, which concern to general relationship pattern between actors.

According to Marteleto (2001, apud Tomaél, Alcará and Di Chiara, 2005), social networks consist of autonomous participants who, nevertheless, share interests and values. Thus, networks are formed by establishing horizontal cooperation relations between individuals, and are characterized by being non-hierarchical, nonlinear, decentralized, flexible, and dynamic, with no limits and self-organizing structures (Tomaél, Alcará and Di Chiara, 2005).

The insertion of the individual in an academic or in a business social network is determinant for sharing information and knowledge. This exchange is a prerequisite for the knowledge construction and for the innovation resulting from it (Tomaél, Alcará and Di Chiara, 2005). We consider business social networks those formed by individuals who develops a relationship based on the professional activities they perform. Those kinds of networks materialize by attendance or by interactions mediated by information technology resources, like virtual networks.

Human networks integrate people in a participatory and a democratic way, facilitating the implementation of policies and projects. This is due by the fact that placing its members in networks encourages teamwork. Furthermore, because of their flexibility, informal networks are able to greater adaptability. They help their members to acquire new skills and update their own knowledge (Chapman, 2009).

The electronic revolution, with the advent of information technology, increased people's information access, promoting the consolidation of the Information and Knowledge Society. Due to these changes, the pyramidal structure of organizations has been gradually replaced by sharing networks, also called collaborative social networks (Carvalho, 2009).

The great challenge of present time is to make the organization able to sharing knowledge. Hence the value acquired by business networks, because it is expected that sharing information impacts on financial assets, as a result of organizational learning (Tomaél, Alcará and Di Chiara, 2005).

According to Tomaél, Alcará and Di Chiara (2005), organizational learning aims for innovation. Innovation, in turn, would result from organization employees' individual skills improvement, and also from the synergy reached when several individuals work together to solve problems, create new products, or improve corporate processes. In such a context, pre-existing mental models are often confronted, challenged and changed.

Cross and Thomas (2009) pointed out that, although many organizations have talented people with the skills required to promote substantial innovations, they do not have available networks that interconnect those talents in order to promote the necessary synergy between the various skills attributed to different individuals. They consider that one main obstacle to innovation within the organization is the failure to collaboration between the talents and skills available.

In this sense, they recommend flexibility and agility to reallocating human resources, interfering in their own internal networks configuration, whether formal or informal. Besides the redistribution of resources, Cross and Thomas (2009) suggest the use of process mapping combined with network analysis, because of the benefits that using these tools bring to the organization, to the extent that their findings impact on the work and on the decision-making processes (Cross and Thomas, 2009).

In summary, the organizational performance improvement, as well as the innovation increment, depends largely on the organization's ability to pool their resources, creating productive collaborations by putting together people with relevant skills and decision-making power (Cross and Thomas, 2009).

Leitner and Grechenig (2008) and O'Murchu, Breslin, and Decker (2007) comment on the growing emergence of virtual social networks mediated by electronic portals, for specific purposes ranging from social interaction to sharing scientific and professional information. These networks, whose vertices (participants) are interconnected through the Information Technology tools, offer the possibility of interaction between people registered, forming groups with similar interests.

Virtual social networks bring important contributions, such as to put in contact, instantly, individuals situated in distant places. Regarding to professional or business networks, as well as academic and scientific networks, we emphasize that, in this virtual interaction context, information exchange is facilitated, encouraging both participants' continuous learning and best practices establishing, among other benefits to its members and to the organizations to which they are linked. 
Thus, organizations that encourage its employees to integrate virtual communities of knowledge sharing are ahead on organizational learning and information and knowledge management issues. The existence of internal communication (intranet) is also relevant. The virtual enterprise network is an effective tool for corporate communication. If the corporate portal is structured on an interactive platform, it should intensify the exchange of relevant information, in a more quickly way than conventionally - by face meetings and document routing through physical means - and can impact positively on the work processes and on business decision-making.

In this sense, business social networks can set up a break with the stagnation and with feelings of worthlessness, and bring new meaning to the professional performance. The continued exchanges and the possibility of being heard and valued are intrinsic motivating elements when someone belongs to a social network focused on her job. In this case, the motivation stems from the professional's perception that he is able to act on the improvement processes and to modify his working environment, both in the micro and the macro perspectives.

The academic environment, beyond mediating experience and knowledge exchanges, encourages people's continuous development. In a learning context, usually is built a support network among students, who help each other in a collaborative attitude that sometimes isn't noticed in work relationships, where competition is often the praxis.

In a specific circumstance of corporate education, where students are mostly members of the same organization, or members of related institutions, such as occurs in MBA courses offered by Cefor, for instance, exchanges established in the classroom enhances the formation of a business social network, in the extent that relevant stakeholders are being identified and recognized. This business social network can be the embryo of organizational learning processes. Thus, we consider important to develop mechanisms for strengthening linkages and for maintenance, in the workplace, of the collaborative attitude started in the academy.

Concluding, networks are very powerful. They have the power to disseminate information, to introduce and crystallize manners, to mobilize communities around specific topics and to join collective efforts to rescue victims and needy. Business network's strength and performance cannot be disregarded by managers, who must use them for the organization, in the processes of culture changes, of knowledge building and dissemination, of strategic alignment and of innovation.

\subsection{Psychological Theories of Motivation}

Scientific research and common belief conceptions both indicate the importance of motivation for people's performance at work. It seems clear that the motivational factor is relevant to explain the individuals' engagement in their tasks and work activities. Thus, when we evaluate the job performance, related to "to want to do", "to know-how to do" and "to be able to do", motivation is a critical factor for the first element.

However, an intervention in the individuals and groups motivational process is a great challenge, because involves the determinants of human behavior's complexity. In this way, from the '50s, with the growing recognition of the human factor to organizational performance, motivation became an important research field. Characteristics of individuals, tasks and organizational context have been investigated in order to try to understand the relationship between motivation and job performance.

This section presents some motivation theories developed in the Psychology area. Afterward, we discuss the relationship between motivation and the knowledge sharing.

Considering a conceptual view, motivation can be defined as a basic psychological process. In this way, motivation refers to something that activates the individual behavior to move toward an object/objective/goal. It is also related to the intensity and persistence of this behavior.

In the organizational context, the first concerns were to identify the primary needs responsible for the activation of individual behavior, as well as the intensity and persistence of some specific behavior. These theories are named Content Theories (Pérez-Ramos 1990 apud Gondim \& Silva, 2004). We will briefly outline in this chapter the theories developed by Maslow, Herzberg and Alderfer.

Maslow's theory is one of the most widespread theories of motivation. Maslow was a humanist psychologist and he developed a personality theory that was later applied to the organizational context. According to Maslow, human motivation is determined by needs that have a biological origin. The central thesis of this theory argues that the individual behavior is guided by the satisfaction of the needs in a hierarchical sequence of priority.

In this hierarchy, illustrated in a pyramid form, the lower needs are the physiological ones (such as hunger, sleep, thirst, sex), followed by safety needs (stability, protection from physical hazards and emotional). The 
intermediary ones are the social needs (friendship, social interaction, belonging), esteem needs (self, status, recognition) and, the highest, self-actualization (truth, justice, wisdom, meaning).

As a humanist, Maslow considered that the human being is guided, at last, by the self-actualization needs. However, the lower needs must be minimally met. While the lower needs are not met, they motivate behavior. Once attended, they are no longer motivating, and then the higher needs can motivate the individual's behavior (Maslow, 1998).

It is important to emphasize that the self-actualization needs has different characteristics from other needs, because once they are met, they motivate the individual to get ever higher levels of achievement and growth.

At this point, we now present a brief description of other motivation theory, named Two-Factor Theory, proposed by Herzberg. The main argument of this theory is that the factors leading to job satisfaction are different from the factors that lead to dissatisfaction. Moreover, in the absence of factors that promote satisfaction, the individual would be in a status of non-satisfaction. Therefore, in the absence of the factors that cause dissatisfaction, individuals assume a status of no dissatisfaction. In this view, organizations should create conditions that promote non-dissatisfaction and stimulate the development of satisfaction (Herzberg, 1986).

This perspective denies the traditional view that satisfaction is the opposite of dissatisfaction. For Herzberg, these two processes are conditioned by different factors. The motivating factors are responsible for the satisfaction. They are related to the work itself - as the activity execution, recognition, content, work meaning, responsibility and personal and professional development and growth - and they are intrinsic. Hygienic factors are responsible for dissatisfaction. They are primarily related to work conditions, such as the organization management policy, relationship with colleagues and superiors, remuneration, and security - they are extrinsic factors.

According to Cavalcanti et al. (2007, p. 94), Herzberg research findings are consistent with Maslow's theory, because "if the needs at the pyramid base are missing, these generate discomfort, but if they are met, they no longer motivate. In their turn, self-actualization, self-respect and self-esteem still motivate if they are achieved".

Following the perspective of content theories, Aldefer (1972) revised Maslow's theory and proposed only three levels of needs. His theory is called ERG Theory. The levels are:

E - Existence - which comprises the physiological and safety needs.

$\mathrm{R}$ - Relatedness - expressed by the social and esteem needs.

$\mathrm{G}$ - Growth - the self-realization need.

According to Aldefer (1972), these levels do not follow a hierarchy and the individual could have progressive and regressive movements along the levels. Thus, the frustration to achieve higher needs would lead the person to regress to the lower needs, where previously got satisfaction. This movement is called "The Principle of Frustration-Regression". In addition, more than one need could determine an individual's behavior simultaneously.

Table 4 presents a summary of the three approaches before described.

Table 4. Summary of Maslow's, Herzberg's and Aldefer's theories

$\left.\left.\begin{array}{c|c}\hline \text { HERZBERG } \\ \text { Motivators } \\ \text { (related to the work itself) } \\ \text { Hygiene Factors }\end{array}\right\} \begin{array}{c}\text { MASLOW-actualization needs } \\ \text { Self-Respect and Self Esteem } \\ \text { Social needs } \\ \text { Safety needs } \\ \text { Physiological needs }\end{array}\right\}\left\{\begin{array}{c}\text { Growth } \\ \text { Relatedness }\end{array}\right\}$

After this brief presentation of some content approach theories, we will emphasize the description of Victor Vroom's Expectancy theory. Basically cognitive, such a theory is categorized as a process theory that highlights the mental processes of perception, decision, assigning meaning, among others, involved in the motivational process that leads individual to action. 
According to Victor Vroom, motivation is the product of three variables: Valence, Instrumentality and Expectancy. Valence is the importance given by the individual to a particular reward. This importance is unique to each person and may change during time. The Instrumentality concerns to the individual's perception of the relationship between their behavior and the scope of the reward. Expectancy is the individual's expectation that, if he/she behaves in a certain way, will be rewarded. Thus, motivation is proportional to the importance that an individual give to the reward related to a specific performance or performance expectation. According Kanfar (1990, apud Gondim \& Silva, 2004), Vroom's theory is considered moderately close to the action, validating theories of empirical content.

Finally, we discuss the motivational perspective developed by Schwartz (1992). This theory can be viewed as an attempt to articulate theories of content and process (Tamayo, 2003). Schwartz started his extensive work aiming to investigate the individuals' axiological structure. Applied to studies on motivation, he developed the premise that values are cognitive representations of needs, representing not only individual needs but also the cultural demands. In this sense, the values act as mediators of the relationship between the needs and goals of the individual.

The motivational process could be described as follows: it has its origin in the needs, which are cognitively represented by the values which, in turn, carry out mediation between the needs and goals and individual's intentions. The goals and intentions are the antecedents of behavior, which is followed by some kind of reward and would result in the experience of satisfaction by the individual. In the words of Tamayo \& Paschoal (2003): "the role of values in motivation is essential because they provide cognitive and cultural meaning for the needs, turning them into goals and intentions. The values are considered motivational goals, which express motivational goals underlying values of people."

In his research, Schwartz built a model of motivational structure, based on the identification of ten drivers, arranged in a two-dimensional structure. The ten identified motivations and motivational goals arising (Tamayo $\&$ Paschoal, 2003) are shown as follows:

- Self-direction - someone has autonomy to decide for himself/herself and/or participate in decisions, control the organization and the execution of his/her job.

- Stimulation - someone suffer challenges in life and work, explore, innovate and have strong emotions in life and job, acquiring new knowledge.

- Hedonism - someone seeks pleasure and avoids pain and suffering, having satisfaction and well-being at job.

-Achievement - someone has personal success and show his/her ability and influence, gaining success in personal and professional life.

- Power - someone that have good reputation and social status, keeping control and dominion over people and professional affairs.

- Security - someone that gets personal and familiar integrity, in an environment that provides job security, included in a harmonic and stable society.

- Conformity - someone that control impulses, tendencies and behaviors, which could be harmful to others and violate norms and expectations of society and organization.

- Tradition - someone that respects and accepts ideas and customs of society and organization.

- Benevolence - someone that seek the welfare of families and persons in the reference group.

- Universalism - someone that seeks understanding, tolerance, protection of nature and well-being for everyone in society and the organization where he/she works.

According to this theory, the personal motivational structure is the set of motivations or goals that move their behavior and relations between these motivations. The motivational profile refers to the importance that each person gives to the various motivations that guide their lives. Thus, the motivational structure is the basis or matrix to elaborate the motivational profile.

Through this framework and the tools developed (Schwartz Values Inventory and Profiling Survey of Values), Schwartz argues that is possible to identify the motivational profile of individuals and groups and, thus, he develops motivational strategies work more efficient, since it would correspond directly to the worker's goals and values (Paschoal \& Tamayo, 2003). 
As we explain about motivation and work, henceforth it is presented factors that influence sharing knowledge, based on Ipe (2003) and Bock et al. (2005) models related to the process of sharing knowledge, addressing the motivational aspects.

Through an extensive theories review, Ipe has built a theoretical model of factors related to knowledge sharing between individuals in organizations. According to her (2003), there are abundant studies addressing why knowledge management is important, but far fewer about how to do it, i.e., there are few studies on the processes necessary to identify, capture, share and use knowledge within organizations.

In this sense, she assumes that knowledge exists in multiple levels in the organization and the individual plays an essential role. Based on the approach of Nonaka and Takeuchi (1995), she argues that the organization cannot create knowledge without individuals, and sharing a particular individual knowledge with other individuals and groups create conditions to knowledge better influence organizational effectiveness.

Thus in her model, Ipe (2003) seeks to identify factors that are involved in sharing and she discusses about the level of individual analysis. She defines the information sharing at this level as the voluntary act of making knowledge available to others, without any obligation to do it. She identified four factors that affect the possibility of knowledge sharing among individuals in the organization: nature of knowledge, opportunities to share, motivation share and organizational culture.

Nature of knowledge refers to the distinction between tacit and explicit knowledge. Explicit Knowledge would have a natural advantage for being shared, considered it tends to be more easily encoded, stored and transferred across time and space. However, this does not mean that it is easily shared within organizations. Ipe (2003) also identified the value of knowledge as a relevant factor in the nature of knowledge. When a high value is assigned to knowledge - for example, the relevant commercial value of knowledge or the importance related to status, promotion or recognition - the knowledge sharing would be mediated by a series of decisions about sharing an specific knowledge with whom and when, and which are the losses and gains in sharing.

Considering the motivation to share, Ipe (2003) declares that motivational factors involved in the knowledge sharing can be classified in two categories:

- Internal factors related to power and reciprocity. When knowledge is perceived as a source of power, its share comes to be mediated by strategies of control and defense. Reciprocity, giving and receiving knowledge can turn easier the knowledge sharing, when individuals recognize that positive value is assigned to this action. Furthermore, reciprocity can hinder sharing when the individual is afraid of being exploited by being sued to share valuable knowledge without the expectation of getting some positive feedback.

- External factors related to the relationship between the receiver and the reward for sharing. The relationship between sender and receiver would involve two elements: trust and power of the receiver. The perception of trust turns easier sharing knowledge. Moreover, the power of the receiver has influence on the share process. Individuals with less influence power tend to direct their communication to those with more influence power, in order to avoid information that could get them vulnerable. The tangible rewards for sharing are also considered as important factors for Ipe (2003), although she highlighted that there is controversy in the literature about this factor. Some studies would indicate a positive influence of tangible rewards and others would indicate a negative one.

Opportunity, considered as a factor of sharing knowledge, is divided into formal opportunities and informational opportunities. Intentional learning channels, which include systems for training and development, work teams and structured technological systems that facilitate sharing would represent formal opportunities. Meanwhile, the informal opportunities would be formed by relational learning channels, which would include social networks and personal relationships. Although the channels are intentionally a very important role for the share, Ipe (2003) identified that research shows that majority of sharing knowledge happens in informal scenarios, which facilitate communication face to face and encourage the building of trust among individuals.

Finally, the author emphasizes that all these factors are influenced by organizational culture. Organizational culture has been recognized as the main barrier to effective creation, sharing and using knowledge. Ipe (2003) highlights that factors alone do not exert their influence. However, they are all influenced by organizational culture. The factors are interrelated and, if all four ones are favorable, it is possible to create a favorable environment of sharing.

In Brazil, researches related to factors that influence the knowledge sharing are rare. We found only one research using the Ipe's model. Alcará et al. (2009) investigated factors that influence the sharing of a Brazilian 
researchers group, which were part of a formal network, comprising universities and research centers. The research results identified trust, friendship, kinship, harmony and giving as motivators for sharing. Another important factor was the obligation to share in the sense that, in order to meet shortfalls in their research centers, the researchers felt the need to use the structure of other centers and this meant that knowledge sharing was necessary. The main barrier identified was the lack of trust between network actors.

Finally, we discuss the study developed by Bock et al (2005). These authors were motivated by understanding factors that support or inhibit individuals' knowledge sharing intentions. They argue that knowledge sharing behavior is influenced by personal and contextual factors motivation. Just as Ipe (2003), they agreed that knowledge sharing is a voluntary act; it cannot be forced, but it only can be stimulated and facilitated.

Bock's model (2005) identifies the following motivational drives, as shown on Table 5:

Table 5. Bock's motivational drivers

\begin{tabular}{ccc}
\hline Economic & Social-psychological & Sociological \\
\hline Anticipated Extrinsic Rewards & Anticipated Extrinsic Rewards & Fairness \\
& Sense of Self- Worth & Innovativeness \\
& & Affiliation \\
\hline
\end{tabular}

Source: Bock et al (2005)

The anticipated extrinsic factor rewards did not find empirical support in the direction expected by researchers, in view of the fact that it did not show a positive correlation with the attitude toward knowledge sharing. Other factors already found empirical support, indicating a positive correlation with attitude, norm subjectivity or intention to share knowledge. We did not found any Brazilian study using this framework.

\section{MBA Program of the Chamber of Deputies in Brazil: A Brief History}

According to the Institutional Developed Plan of the Capacitation, Training and Improvement Centre - Cefor (Brasil, 2008) the creation of a space for training civil servants in the area of human resources in order to provide adequate support for the consolidation and development of the Employee Career Plan of the Chamber of Deputies was already foreseen in 1992. But, only in 1997 Cefor was created with broad powers that allow it to develop training courses to support the career plan, the extent of these and other actions to the community. The ability to carry out agreements for exchange and mutual cooperation with authorities and public institutions and private provision of services related to its activities and institutional purposes and the development and implementation of programs, projects and training activities was included in skills of Cefor.

The first activities of Cefor consisted of a public examination and training of civil servants to meet the demands of the various organs of the Chamber of Deputies. Over time, the Center's activities were expanding. Currently, it provides courses, conferences and other activities, both in person as at the distance, not only for the approximately 12,000 employees in the Chamber of Deputies, but also to a diverse audience, which include politicians, civil servants from other institutions, students of institutions of higher education, among others. Within this broad range of performance, Cefor has reached an average of 10000 people. These numbers demonstrate the vitality of the organ, whose performance has been marked by meticulous planning activities, implementation and evaluation. In the experience of almost ten years of operation, the Centre has been consolidated as a dynamic center for continuing education of the civil servants of the Chamber of Deputies and its partners. (Brasil, 2008)

The expansion of activities and growth of its audience, as well as an increasing demand for higher education, led the Cefor to sign an agreement with the University of Brasilia (UnB) in 1998 to perform lato sensu post-graduation (MBA). Two courses were made: a MBA in Management Development, with four successive classes, and another, in Legislative Management with two classes, 182 students in whole. In 2003, with the maturation of these activities and the consequent increase in its demand, the portfolio of the institution offered in addition to the aforementioned courses, a MBA in Human Recourses Management, developed in partnership with the Federal University of Minas Gerais (UFMG). Thus, Cefor professionals began studies for the creation of a Graduate Program maintained by Chamber of Deputies, in order to improve the "Legislative Wisdom" by developing academic knowledge in the Chamber of Deputies. The process was completed in 2004 and sent to the Ministry of Education (MEC) for approbation. 
In January 2005, the Program for Graduate of Cefor was approved by MEC. The first student's selection occurred in August of that year for the courses of specialization and expertise in the "Legislative Process in Institutions" and "Political Processes of the Legislative". Also in 2005, through a partnership with the Institute Serzedello Corrêa of the Court of Audit (TCU), agency also accredited by the MEC, Cefor collaborated to launch a third course: MBA in Public Budget. The offering of these three courses enabled the Program Graduate of Cefor to act in key areas of legislative branch, namely the legislative action, the evaluation of government actions, with emphasis on the control of public accounts, and political representation and its horizon in the promotion of democracy. (Brasil, 2008)

In addition of offering courses, the MBA Program has included, since 2006, the formation of Research Groups and Extension (GPE). In these groups, the graduates of the specialization courses, teachers, employees and other stakeholders in thinking about the Parliament and democracy, regardless of a formal link with the Chamber of Deputies, are encouraged to develop research and other studies with goal of establishing a network consisting of production of specific knowledge and strategic to the Parliament.

Also in 2006, moving towards deploying MBA studies, the MBA Program has partnered with University Research Institute of Rio de Janeiro (Iuperj) to provide for teachers, graduates and other employees effective Master and PhD courses . Classes began in December 2006 and finished in 2009 for 20 masters students, and in 2010 for $10 \mathrm{PhD}$ students.

In parallel, the MBA Program studies start to offer E-learning courses, trying to meet the demands of other legislative houses. The result was the creation of an educational project of the MBA in Legislative Process, semi-distance regime. As the accreditation of the program provided only for classroom courses, Cefor joined in October 2006, with applications for accreditation also for lato sensu post-graduation in the new mode. (Brasil, 2008)

In 2009, it was created the MBA in Legislative and Public Policy, to cover the needs of monitoring of government actions from the constitutional functions of the Legislature. Also in 2009, the MBA in Public Management Legislative was started to address the need for professionalization of the employees in the administrative area of the Chamber of Deputies.

The MBA in Legislative and Public Management was created in 2010 to fulfill a gap in administrative area of the Chamber of Deputies.

\section{Research Methodology}

The research that supports this chapter was developed in three phases: a bibliographical and documental research, and also a survey with MBA students. The bibliographical research was developed to build a framework where Knowledge Management, Social Networks and Motivation Theories sustained the business social networking in a group of students in the context of Chamber of Deputies MBA Program. The documentary research was based on internal documents of the Chamber of Deputies about the MBA Program and its features.

Finally, the third and more complex part of the research was the survey. The follow steps were developed:

\section{$1^{\text {st }}-$ Chosen the population}

The population chosen comprises 81 MBA students in three blocks: one refers to the Legislative and Public Policies - LPP, integrated by 30 students that ended all disciplines in the MBA and enter now in a phase to prepare a Completion of Course Work. This group does not interact personally in a class anymore, just using technological resources to meet each other or eventual meetings. The second group is formed by 21 students of the Legislative and Public Management - GPL that still interact personally in a classroom. As well, the third group of 30 students coursing Legislative Process interact personally and they begin the course in august, 2010 and ended in July 2011. The three kinds of groups were chosen to establish differences between them in terms of socializing knowledge.

\section{$2^{\text {nd }}-$ Developed and Applied the instrument to collect data}

This phase comprised the elaboration and application of a questionnaire to students in two conditions: the group of LPP received the instrument by e-mail, on august $16^{\text {th }}, 2010$, considering the difficult to gather them in the same place. The group of GPL and PL answered the questions on August $20^{\text {th }}, 2010$, during the classes. Before applying the final version of the questionnaire, a "survey test" was accomplished with 3 persons that have the same features of the two groups of MBA students. The results supported improvements on the questionnaire.

The final version of the questionnaire is on appendix.

$3^{\text {rd }}$ - Tabulated Data 
Using the resources of Ms Excell, particularly descriptive functions, cross references among data was developed in order to find out relations and tendencies that support conclusions about the way of the two different group of students share knowledge.

\section{Variables}

In this research, we consider three groups of variables to identify particularities of the population studied as follows:

- Demographical data: these data are related to gender, age, MBA on Cefor, bachelor course, bachelor course age of conclusion, degree, work organization, during working time on organization and working time on legislative affairs.

- Pattern of sharing knowledge data: this group seek to comprehend the perception of the inquirers about sharing knowledge related to MBA subjects, Legislative or personal life, considering the view from the respondent, from his/her classmates and among all students.

- Factors that lead to share knowledge data: the motivational factors were defined by a comparative study among Ipe (2003), Bock et all (2005), Schwartz (1992), Vroom (1964) and Aldefer (1972), according to Table 6. In fact, the final motivational factors considered were: affiliation, self-actualization, auto recognization, conformity, fairness, hedonism, innovativeness, power, reciprocity, rewards, relationship and safety.

Table 6. Comparison among Ipe's, Bock's, Schwartz's, Vroom's and Aldefer's Theories

\begin{tabular}{|c|c|c|c|c|c|}
\hline \multirow{2}{*}{ Factor } & \multicolumn{5}{|c|}{ Researcher's Theories } \\
\hline & IPE & BOCK & SCHWARTZ & VROOM & ALDEFER \\
\hline Achievement & & & $\mathrm{X}$ & & \\
\hline Affiliation & & $\mathrm{X}$ & & & \\
\hline Conformity & & & $\mathrm{X}$ & & \\
\hline Existence & & & & & $\mathrm{X}$ \\
\hline Expectancy & & & & $\mathrm{X}$ & \\
\hline Fairness & & $\mathrm{X}$ & & & \\
\hline Growth & & & & & $\mathrm{X}$ \\
\hline Hedonism & & & $\mathrm{X}$ & & \\
\hline Innovativeness & & $\mathrm{X}$ & & & \\
\hline Instrumentality & & & & $\mathrm{X}$ & \\
\hline Power & $\mathrm{X}$ & & $\mathrm{X}$ & & \\
\hline Reciprocity & $\mathrm{X}$ & $\mathrm{X}$ & & & \\
\hline Relationship & $\mathrm{X}$ & & & & $\mathrm{X}$ \\
\hline Rewards & $\mathrm{X}$ & $\mathrm{X}$ & & & \\
\hline Safety & & & $\mathrm{X}$ & & \\
\hline Self-Direction & & & $\mathrm{X}$ & & \\
\hline Sense of Self-Worth & & $\mathrm{X}$ & & & \\
\hline Stimulation & & & $\mathrm{X}$ & & \\
\hline Tradition & & & $\mathrm{X}$ & & \\
\hline Valence & & & & $\mathrm{X}$ & \\
\hline
\end{tabular}

Considering the results from Table 6 , factors are merged by their notions and it was used the most frequently. The factor chosen and their respective operational concepts are presented as follows:

- Affiliation: The perception of togetherness in a group makes me share knowledge

- Achievement: The capacity to motivate myself in sharing knowledge allows me to do my job well 
- Sense of Self-Worth: I share knowledge because I feel myself recognized by my workgroup while creating value in sharing contributions to the organization

- Conformity: I share knowledge in respect to organizational rules and social conventions

- Fairness: The feeling that exists equitable treatment in a group makes me share knowledge

- Hedonism: The seek for satisfaction and well-being makes me share knowledge

- Innovativeness: The encouragement of a team to express new ideas and explore a few knowledgeable areas makes me share knowledge

- Power: I share knowledge as I keep or increase my influence in a group

- Reciprocity: I share knowledge considering the possibility to exchange, give and receive knowledge

- Rewards: I share knowledge because I have external rewards (for example, financial retribution)

- Relationship: I share knowledge among people I am closed and I trust

- Safety: I share knowledge to guarantee personal security and job stability

\section{Findings}

\subsection{Demographical Analysis}

The questionnaire to assess the knowledge sharing pattern in Cefor MBA classes was applied to students of the three courses in progress at this time. From 81 students enrolled in these classes, $56(69 \%)$ answered it. The questionnaire was applied by the researchers at PL's class (at the first month of the course) and in GPL's class (6 months from the beginning of the course, corresponding to the "middle" of the mandatory classes). Considering that LPP's students do not have classes anymore (they are at the end of the course, about 12 months) and considering they are preparing their conclusion course paper, the e-mail was the tool to access them. The process to gain answers to the questionnaire may explain the higher adhesion of the students in the PL and GPL classes for the quiz, making up $90 \%$ in these classes, and only 33\% in LPP's class.

Considering the variable gender, $30(54 \%)$ subjects were male and $26(46 \%)$ are female. As age group, 11 respondents have between 21 and 30 years, 13 respondents between 31 and 40 years, 24 individuals have between 41 and 50 and two guys are over 50 years.

Concerning to the respondents undergraduate area, the sample is heterogeneous and there are 39 undergraduate students. Most respondents are from Law (12 subjects) or Business (12 subjects). The rest of them are from several fields such as Literature, Architecture, Chemistry, Economics, Psychology, History and other Social Sciences. On the other hand, 12 respondents are experts and five one are Master in Science. 49 students work on different areas of the Chamber of Deputies, five of them work in different areas of the Legislative Chamber of the Federal District and one works in business consulting.

Finally, 29 students are experts in legislative affairs, considering they are working on Legislative area over 10 years) and 27 are novices. Among newcomers, 18 respondents work in the Legislative for less than 5 years, and among the experts, 15 students work in the Legislative area more than 17 years. One subject is over 26 years experienced in Legislative.

Concluding the demographical analysis, it is possible to summarize that the sample is characterized by heterogeneity, considering that the link between all of the respondents is the relationship with the Legislative and the professional training investment. There is a great diversity in the undergraduate area, in the specific Legislative job and in the experience time in this area. The students are people with high educational level, many of them attending the second MBA in a mature age, suggesting commitment to their career development.

\subsection{Analysis of Sharing Knowledge Pattern}

We seek to investigate the pattern of sharing knowledge among members of the three classes of the MBA in Chamber of Deputies. The sharing pattern was studied from the student's perspective of the degree to which knowledge is shared according to the following categories:

- Degree of sharing knowledge in the roles of donor and receiver (Note 1) and also the perception degree of the group knowledge sharing.

- Sharing knowledge about the MBA, the job in Legislative field or the personal life.

It was used a Likert Scale (Note 2) of five points, where 1 means "the student does not share knowledge" and 5 meant "the student shares a lot of knowledge." 
Table 7 presents the results obtained from the general pattern of knowledge sharing, using the categories listed above.

Table 7. General pattern of knowledge sharing

\begin{tabular}{|c|c|c|c|c|c|}
\hline Roles & $\mu \sigma c_{v}($ Note 3$)$ & MBA Subjects & Legislative Subjects & Personal Life & General Average \\
\hline & $\mu$ & 3,29 & 3,59 & 2,84 & \\
\hline \multirow[t]{3}{*}{ Donor } & $\sigma$ & 1,09 & 1,11 & 1,20 & 3,24 \\
\hline & $c_{v(\%)}$ & 33,19 & 30,88 & 42,36 & \\
\hline & $\mu$ & 3,45 & 3,30 & 2,73 & \\
\hline \multirow[t]{3}{*}{ Receiver } & $\sigma$ & 1,04 & 1,08 & 1,12 & 3,16 \\
\hline & $c_{v(\%)}$ & 30,27 & 32,61 & 40,98 & \\
\hline & $\mu$ & 3.41 & 3,13 & 2,69 & \\
\hline \multirow[t]{2}{*}{ Group Process } & $\sigma$ & 1,09 & 1,13 & 1,03 & 3,17 \\
\hline & $c_{v(\%)}$ & 32,01 & 36,18 & 38,43 & \\
\hline \multicolumn{2}{|c|}{ General Average } & 3,28 & 3,34 & 2,75 & \\
\hline
\end{tabular}

It is observed that all the general averages are above 2.7, suggesting that participants perceive at least a moderate level of knowledge sharing. Considering the perception about shared knowledge level, the results point that the average for $\mathrm{MBA}$ is 3.38 and 3.34 for activities related to the job in the legislative affairs, indicating the perception of the subjects with moderate to good level of sharing expertise. Importantly, the standard deviation and coefficient of variance for these categories do not indicate large variability in responses among participants. It appears also that the thematic focus "Personal Life" is the one with the lowest overall mean $(\mu=2.75)$ and the indexes of standard deviation and coefficient of variance indicate a greater variability of responses among respondents.

These results suggest a pattern of knowledge sharing more intense and homogeneous in "MBA" and "Working a Legislative", indicating the formation of a business social network among the participants of the courses of MBA in Cefor, while the students perceive a good degree of sharing of both the themes and issues related to the specialization that evolve together, as the experiences of work each one has in the Legislature. Accordingly, it can be argued that the specialization course has influenced as a facilitating environment for the formation of a business social network among their students.

However, although with lower scores and greater variability of responses, we must also consider the importance of sharing in the thematic focus "Personal Life", which points to the formation of social ties among students, who are experienced in a more heterogeneous way than the bonds of social networking and work.

On the other hand, analyzing the perception of sharing using the categories "Donor", "Receiver" and " Group Process", it is observed that all the general average are above 3.0, while the category "Donor" had an average overall slightly superior to others.

In the simultaneous analysis of the categories, it appears that participants perceive that sharing knowledge about the "Work in the Legislative" is highest when they are in the role of donors $(\mu=3.59)$. In addition, the results show that there is a greater sharing of knowledge on the "MBA" when they are in the role of receivers $(\mu=3.45)$. These results indicate the willingness of participants to share experiences with peers and knowledge related to their work practice in the Legislature. Furthermore, students perceive receiving information and theoretical knowledge about the course. In this sense, we perceive a link between explicit and tacit knowledge in the process of sharing the expertise developed over. As for the group process, participants perceive a greater share of the group in the "MBA" $(\mu=3.41)$.

Table 8 shows the results of the sharing pattern in all groups of students surveyed: 
Table 8 . Knowledge sharing pattern by MBA

\begin{tabular}{lcrrrrrrrrr}
\hline \multirow{2}{*}{ Roles } & \multirow{2}{*}{$\boldsymbol{\sigma} \boldsymbol{c}_{\boldsymbol{v}}{ }^{4}$} & \multicolumn{3}{c}{ MBA Subjects } & \multicolumn{3}{c}{ Legislative Subjects } & \multicolumn{3}{c}{ Personal Life } \\
\cline { 2 - 10 } Donor & $\boldsymbol{\mu}$ & $\mathbf{P L}$ & $\mathbf{G P L}$ & $\mathbf{L P P}$ & $\mathbf{P L}$ & $\mathbf{G P L}$ & $\mathbf{L P P}$ & PL & GPL & LPP \\
& $\boldsymbol{\sigma}$ & 1,06 & 1,07 & 1,03 & 0,88 & 1,12 & 0,88 & 0,97 & 0,99 & 0,99 \\
& $\boldsymbol{c}_{\boldsymbol{v}(\%)}$ & 35,62 & 30,90 & 27,18 & 29,24 & 29,24 & 22,45 & 33,72 & 25,53 & 25,50 \\
\hline \multirow{4}{*}{ Receiver } & $\boldsymbol{\mu}$ & $\mathbf{3 , 0 0}$ & $\mathbf{3 , 8 4}$ & $\mathbf{3 , 9 0}$ & $\mathbf{3 , 1 1}$ & $\mathbf{3 , 2 1}$ & $\mathbf{4 , 0 0}$ & $\mathbf{2 , 5 9}$ & $\mathbf{2 , 9 5}$ & $\mathbf{2 , 7 0}$ \\
& $\boldsymbol{\sigma}$ & 1,12 & 1,17 & 0,88 & 1,12 & 1,03 & 0,82 & 1,10 & 1,13 & 1,06 \\
& $\boldsymbol{c}_{\boldsymbol{v}(\%)}$ & 31,89 & 34,19 & 21,36 & 36,03 & 32,13 & 20,41 & 34,91 & 40,66 & 28,63 \\
\hline \multirow{2}{*}{ Group } & $\boldsymbol{\mu}$ & $\mathbf{2 , 9 8}$ & $\mathbf{3 , 8 9}$ & $\mathbf{3 , 9 0}$ & $\mathbf{3 , 1 5}$ & $\mathbf{2 , 7 9}$ & $\mathbf{3 , 7 0}$ & $\mathbf{2 , 5 9}$ & $\mathbf{2 , 8 3}$ & $\mathbf{2 , 7 0}$ \\
\multirow{2}{*}{ Process } & $\boldsymbol{\sigma}$ & 1,07 & 1,12 & 1,65 & 0,97 & 1,13 & 1,49 & 0,80 & 1,25 & 1,25 \\
& $\boldsymbol{c}_{\boldsymbol{v}(\%)}$ & 35,81 & 39,36 & 68,61 & 37,46 & 38,31 & 55,35 & 30,74 & 44,07 & 46,36 \\
\hline
\end{tabular}

It is observed that students of the LPP obtained higher scores both in the category of "MBA" and in the category "Work in the Legislative", with average around 4.0. This is the group that begins the course earlier, after a year of studying together, which may explain the fact that we can perceive more knowledge sharing than among other groups. However, it is noteworthy that, in the category "Process Group", there is a great variability in responses, with a coefficient of variance of 68.61 (in perceptual), indicating that, in the end, it may have been developed a formation of subgroups and the perception of unequal sharing of knowledge between members of the group when they analyze the group process.

The category "Personal Life", firstly shows less difference between the averages of three groups of students and, secondly, the greater variability of responses.

\subsection{Analysis of Factors that Lead to Share Knowledge}

Table 9 shows the knowledge sharing motivator factor's importance order in the total sample.

Table 9. Knowledge sharing pattern by MBA

\begin{tabular}{ccccc}
\hline Order & GENERAL & PL & GPL & LPP \\
\hline $1^{\text {o }}$ & Relationship & Relationship & Relationship & Innovativeness \\
$2^{\text {o }}$ & Sense of Self-Worth & Sense of Self-Worth & Reciprocity & Reciprocity \\
$3^{\text {o }}$ & Reciprocity & Reciprocity & Affiliation & Sense of Self-Worth \\
$4^{\text {o }}$ & Affiliation & Affiliation & Innovativeness & Affiliation \\
$5^{\text {o }}$ & Achievement & Achievement & Achievement & Relationship \\
$6^{\text {o }}$ & Innovativeness & Innovativeness & Hedonism & Achievement \\
$7^{\circ}$ & Hedonism & Hedonism & Sense of Self-Worth & Conformity \\
$8^{\circ}$ & Sonformity & Conformity & Conformity & Safety \\
$9^{\circ}$ & Power & Safety & Power & Hedonism \\
$10^{\circ}$ & Rewards & Power & Safety & Rewards \\
\hline
\end{tabular}

It must be considered the context in which participants are inserted: all of them are inserted on MBA regular course and they were encouraged to express how they perceive the knowledge sharing with their peers. As such as described by Ipe (2003), one of the factors manifested in knowledge sharing is the opportunity of sharing what 
occurs in intentional learning channels and relational learning channel. The MBA is initially an intentional learning channel that can also be a context for the creation of relational learning channels.

In this sense, it is observed that among the five first motivational factors of knowledge sharing, four of them are linked to respondents' relation with group and peers. Belonging, group interaction, place in the group, trust and friendship seem to favor knowledge sharing in the sample. These results confirm the importance of factors already identified in literature, as affiliation, anticipated reciprocal relationships (Bock, 2005) and reciprocity and relationship (Ipe, 2003). Furthermore, they point to the importance of social networks for knowledge sharing and reinforce the studied specialization courses context as favoring the formation of social networks. Moreover, they point to context as an important relational learning channel to share knowledge.

Sense of Self-Worth is another factor that deserves mention. In conjunction with relationship, the Sense of Self-Worth is the factor most reported by the respondents as the main motivating factor for sharing. This leads to the intrinsic motivational factors importance, which have traditionally been described by Maslow (need for self-realization), Herzberg (motivational factors) and Aldefer (existential needs).

Moreover, conformity, security, power and rewards are the least mentioned by participants as sharing motivator factors. It is important to consider that the participants are sharing knowledge in an educational context, which promotes the creation of a business social network among the participants. This educational context seems to be less susceptible to power and resources competition than a labor organization context.

By doing a comparative analysis among the three groups, the results do not point to a priority to fairness factor because there was much scatter in the importance order given by respondents.

The analysis of the three groups shows that in Cefor MBA context, knowledge sharing is motivated by emotional and intangible factors. The need to be with each other, to exchanging ideas, information and knowledge, to belonging to a group and to be appreciated by others are the reasons that motivate most students to establish exchanges with their peers. The more pragmatic and tangible factors, such as reward and power, were not prioritized. This indicates that knowledge is not used by respondents to manipulate people or situations. It is perceived objectivity in the act of sharing, which, in turn, is aimed to strengthen ties and to offer and receive support from others.

The variable "time on MBA" seems to have no influence on knowledge sharing motivation, because this motivation was high in all three classes, despite the variation in the time from the course beginning when the questionnaire was applied to sample ( $\mathrm{PL}=1$ month ; $\mathrm{GPL}=6$ months; $\mathrm{LPP}=12$ months).

Comparing the three groups, there is a greater similarity between the results found in PL and GPL groups than on the results of LPP class. The first two classes are focused on the Legislative themes, while the latter deals with public policy, an issue that, despite having interfaces with the Legislative, is primarily an Executive's (Note 4) responsibility. The LPP's class interaction pattern differs from the others, whose dynamic thins with greater interactivity and dialogue common in parliament. Another point to emphasize is the main factor that encourages the knowledge sharing in the LPP's classroom: innovation. Perhaps, the main LPP's students question is to find alternatives to government policies that promote the welfare and the society development, while PL and GPL students will probably seek to understand the operation of Legislative Power. Each courses nature justifies the findings concerning to knowledge sharing motivator factors in Cefor MBA courses.

\section{Future Research Directions}

The research results opened new questions and created some possible interesting themes to discuss. One of them is related to use the Organizational Network Analysis - ONA, to verify if the participation in a Cefor MBA increases the intensity of links created by Legislative employees.

Other future research can deal with the variable fairness. In this study, we were not able to indicate a "place" in the importance order of factors that influence the motivation to sharing knowledge. A third point that can stimulate a new research is the importance of sharing knowledge in a group of coworkers and not just in a training situation.

\section{Final Points}

The study showed that there are differences among MBA students in terms of motivational factors to sharing knowledge. However, there is a tendency in the group of Cefor to value Relationship and Sense of Self-Worth as the most influencing factor to socialize knowledge in a BSN, as shown on Figure 3. 
Other point to emphasize is the well fit of Psychology Theories to support the identification of the factors that interfere on sharing knowledge, in a MBA context. Both classical and novel theories can be integrated to create a framework to investigate motivational factors in BSN.

The last item to highlight is that the Chamber of Deputies in Brazil is creating a new way to establish integration among its civil servants, by using a MBA program as context to sharing knowledge and discuss important themes related to the administrative area of the Legislative.

Thus, we conclude that the main objectives proposed to this chapter were totally achieved and it opens new visions about the Legislative in Brazil.

Figure 3. Influence of Motivational Factor in Sharing Knowledge.

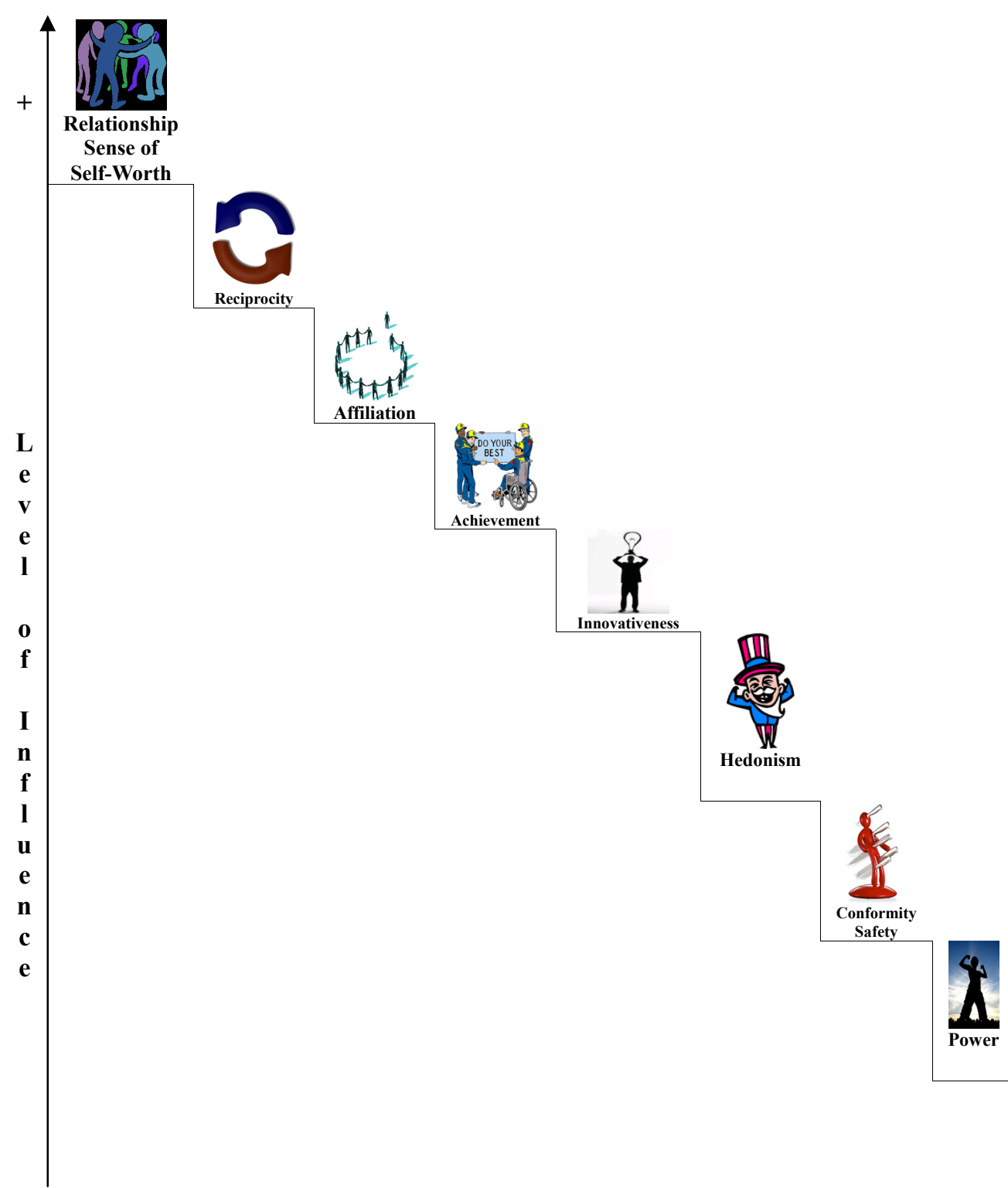

Motivational Factors

\section{References}

Alcará, R. A., Chiara, I. G., Rodrigues, J. L., Tomaél, M. I., \& Piedade, V. C. H. (2009). Fatores que influenciam o compartilhamento da informação e do conhecimento. Perspectiva em Ciência da Informação, 14(1), 170-191. http://dx.doi.org/10.1590/S1413-99362009000100012 
Aldefer, C. (1972). Existence, relatedness, \& growth. New York: Free Press.

Argote, L., \& Miron-Spektor, E. (2010). Organizational Learning: From Experience to Knowledge. Retrieved July 9, 2010, from http://apps.olin.wustl.edu/cres/research/calendar/files/ArgoteL.pdf.

Baskerville, R., \& Dulipovici, A. (2006). The theoretical foundations of knowledge Management. Knowledge Management Research \& Practice, 4, 83-105. Operational Research Society. Retrieved July 9, 2010, from $\mathrm{http}: / / \mathrm{www}$.palgrave-journals.com/kmrp.

Bock, G., Zmud, R. W., Kim, Y., \& Lee, J. (2005). Behavioral intention formation in knowledge sharing: examining the roles of extrinsic motivators, social-psychological forces, and organizational climate. MIS Quarterly, 29(1), 87-111.

Brasil. Câmara dos Deputados. (2008). Plano de desenvolvimento institucional - PDI. Private document. Brasília: Centro de Formação, Treinamento e Aperfeiçoamento. Nov.

Carvalho, K. (2009). Redes sociais: presença humana e a comunicação informal. In D. A. Población, R. Mugnaini, \& L. M. S. V. C. Ramos (Eds.), Redes sociais e colaborativas em informação científica (pp. 141-167). São Paulo: Angellara Editora.

Cavalcante, G. V. (2009). Ciência das Redes: aspectos epistemológicos. Thesis. Departamento de Ciência da Informação e Documentação. Brasília: Universidade de Brasília.

Cavalcanti, V. L., Carpilovsky, M., Lund, M., \& Lago, R. A. (2007). Liderança e Motivação. Rio de Janeiro: Editora FGV.

Changing Minds. (2010). Likert Scale. Retrieved September 27, 2010, from http://changingminds.org/explanations/research/measurement/likert_scale.htm\#des

Cross, R., \& Thomas, R. J. (2009). Redes sociais: como empresários e executivos de vanguarda as utilizam para a obtenção de resultados. São Paulo: Editora Gente. 237 p.

Daft, R. L. (1997). Management (4th ed.). Orlando, Fl.: Harcourt Brace.

Eckert, P. (2000) Linguistic variation as social practice. Oxford: Blackwell.

Gloor et alli. (2008). Location matters - measuring the efficiency of business social networking. Int. J. Foresight and Innovation Policy, 4(3/4), 230-245. Retrieved July 14, 2010, from http://www.vonarb.org/documents/Social_Network_Analysis_Gloor.pdf

Godim, S. M. G., \& Silva, N. (2004). In J. C. Zanelli, J. E. Borges-Andrade, \& A. V. B. Bastos (Eds.), Psicologia, Organizações e Trabalho no Brasil. Porto Alegre: Artmed.

Herzberg, F. (1986, January-February). One more time: How do you motivate employees? Harvard Business Review, 53-62.

Ipe, M. (2003). Knowledge sharing in organizations: a conceptual framework. Human Resource Development Review, 2(4). http://dx.doi.org/10.1177/1534484303257985

Leitner, P., \& Grechnig, T. (2008). Social networking sphere: a snapshot of trends, functionalities and revenue models. IADIS International Conference on Web Based Communities. Retrieved July 12, 2010, from http://www.iadis.net/dl/final_uploads/200810C024.pdf

Lopes, F. D., \& Baldi, M. (2009). Redes como perspectiva de análise e como estrutura de governança: uma análise das diferentes contribuições. Rev. Adm. Pública, 43(5). Rio de Janeiro set./out. Retrieved July 1, 2010 , from http://www.scielo.br/scielo.php?script=sci_arttext\&pid=S0034-76122009000500003\&lng=pt\&nrm=iso

Maslow, A. H. (1998). Toward a Psychology of Being (3rd ed.). New York: Wiley.

Milroy, L., \& Gordon, M. (2003). Sociolinguistics - Method and Interpretation. Oxford: Blackwell.

Nonaka, I., \& Takeuchi, H. (1995). The Knowledge-Creating Company. New York: Oxford University, Press.

O’Murchu, I., Breslin, J. G., \& Decker, S. (2007). Online social and business networking Communities. In Taher N. (Ed.), Viral Marketing: Concepts and Cases. Icfai Books, June. Retrieved July 12, 2010, from http://www.johnbreslin.org/files/publications/20070600_icfa2007.pdf

Robbins, S. P. (2005). Comportamento Organizacional. São Paulo: Prentice Hall. 
Schwartz, S. H. (1992). Universals in the content and structure of values: theoretical advances and empirical tests in 20 countries. In M. Zanna (Ed.), Advances experimental social psychology. New York: Academic Press.

Severo, C. G. (2007). A questão da identidade e o lócus da variação/mudança em diferentes abordagens sociolingüísticas. Revista Letra Magna. Revista Eletrônica de Divulgação Científica em Língua, Lingüística e Literatura Portuguesa.. Ano 4 n.7. $2^{\circ}$ Semestre.

Snowden, D. (2006). Naturalising Knowledge Management. nov. 2006. Retrieved July 9, 2010, from $\mathrm{http} / / / \mathrm{www} . c 0 g n i t i v e-$ edge.com.

Stollenwerk, M. F. L. (2001). Gestão do conhecimento: conceitos e modelos. In K. Tarapanoff (Ed.), Inteligência organizacional e competitiva (pp. 143-163). Brasília: Editora UnB.

Tamayo, A., \& Paschoal, T. (2003). A Relação da Motivação para o Trabalho com as Metas do Trabalhador. RAC - Revista de Administração Contemporânea, 7(4), 33-54. Associação Nacional dos Programas de Pós-Graduação em Administração. Rio de Janeiro: http://dx.doi.org/10.1590/s1415-65552003000400003

Tomaél, M. I., Alcará, A. R., \& DI CHIARA, I. G. (2005). Das redes sociais à inovação. Ciência da Informação. Brasília, 34(2), 93-104, maio/ago. Retrieved July 7, 2010, from http://www.scielo.br/pdf/ci/v34n2/28559.pdf

Vroom, V. H. (1964). Work and motivation. New York: Wiley.

Wenger, E. (1999). Communities of Practice. Learning, meaning and identity. Cambridge: Cambridge University Press.

\section{Notes}

Note 1 . We are calling donor a person who elicit knowledge to other one and receiver a person who captures knowledge from somebody.

Note 2. Likert Scale is an ordered, one-dimensional scale from which respondents choose one option that best aligns with their view.

Note 3. $\mu$-average, $\sigma$-standard deviation and $c_{v}-$ coefficient of variation $(\sigma / \mu)$ presented here in perceptual form.

Note 4. We refer here to the Executive Power, conduct by the President of the Republic.

\section{Copyrights}

Copyright for this article is retained by the author(s), with first publication rights granted to the journal.

This is an open-access article distributed under the terms and conditions of the Creative Commons Attribution license (http://creativecommons.org/licenses/by/3.0/). 